\title{
TRACE ELEMENTS IN RIVER WATERS AND SEDIMENTS BEFORE AND AFTER A MINING DAM BREACH (BENTO RODRIGUES, BRAZIL)
}

Danilo de C. Silva ${ }^{a}$, Carlos R. Bellato ${ }^{a}, *$, José de O. Marques Neto ${ }^{a}$ and Maurício P. F. Fontes ${ }^{b}$

a'Departamento de Química, Universidade Federal de Viçosa, 36570-000 Viçosa - MG, Brasil

${ }^{b}$ Departamento de Solos, Universidade Federal de Viçosa, 36570-000 Viçosa - MG, Brasil

Recebido em 15/02/2018; aceito em 28/05/2018; publicado na web em 26/06/2018

\begin{abstract}
On November 5, 2015, the Fundão dam ruptured which caused the spill of a large quantity of tailings from the extraction of iron ores to the Gualaxo do Norte, Carmo and Doce Rivers. Seven months prior to the rupture, our group had collected water and sediment samples at 13 points along the Tripuí Creek and the entire length of the Carmo River. Six months after deposition of the mud, new samples were collected in the Carmo River. Thus, the present study sought to evaluate the concentrations of trace elements in the waters and their distribution and mobility in sediment by BCR sequential extraction before and after the deposition of the tailings mud. Arsenic concentrations in the water samples were between 10.4 and $50.4 \mu \mathrm{g} \mathrm{L}^{-1}$, which exceeded $10 \mathrm{ug} \mathrm{L}^{-1}$ (maximum limit permitted by Brazilian environmental regulations for water destined for human consumption). The tailing mud layer on the sediments caused concentration increases of As (20\%), Cd (13\%), Co (5\%), $\mathrm{Cr}(9 \%), \mathrm{Cu}(11 \%), \mathrm{Ni}(4 \%), \mathrm{Pb}(7 \%)$ and $\mathrm{Zn}(19 \%)$ in the easily remobilized fractions. The presence of the elements in these fractions was indicative of high ecotoxicological risk and potential harm to the health of the local population.
\end{abstract}

Keywords: Mariana accident; Carmo River; fractionation; sequential extraction; bioavailability.

\section{INTRODUCTION}

On November 5, 2015, one of tailings dams of the mining company Samarco, denominated of the Fundão located in the municipality of Mariana, collapsed and released large quantities of tailings. This was considered the greatest environmental accident in Brazilian mining history. ${ }^{1-3}$ The flow of tailings mud reached the rivers Gualaxo do Norte $(\sim 55 \mathrm{Km})$, Carmo $(\sim 22 \mathrm{Km})$, Doce $(\sim 600 \mathrm{Km})$ and then the Atlantic Ocean on November 22, 2015, in the Brazilian state of Espírito Santo. ${ }^{2}$ The accident caused significant damages, including: native flora of the Atlantic Forest, areas of permanent preservation, destruction of agricultural areas, mortality of aquatic biota and terrestrial fauna water-dependent, devastation of cities, the death of mining workers and Bento Rodrigues residents and other problems. ${ }^{4,5}$ Mud collected directly from the Fundão tailings dam on November 28, 2015 presented $\mathrm{Fe}$ and $\mathrm{Mn}$ as the main elements, as well as trace elements ( $\mathrm{Pb}, \mathrm{As}, \mathrm{Sr}, \mathrm{Zn}, \mathrm{Cu}, \mathrm{Ni}$ and $\mathrm{Co}){ }^{2}$ Deposition of the mud on river sediments (mud layer) can cause remobilization of $\mathrm{As}, \mathrm{Co}, \mathrm{Cu}, \mathrm{Ni}, \mathrm{Pb}, \mathrm{Sr}$ and $\mathrm{Zn}$ to the aquatic environment, resulting in environmental damage. Thus, after the environmental accident in Mariana, which caused the deposit of a layer of mud on sediments of the Gualaxo do Norte, Carmo and Doce Rivers, studies should be conducted to evaluate the distribution and mobility of trace elements in sediment samples and their concentrations in water samples.

In the southeastern region of the Iron Quadrangle (IQ), arsenic is distributed in close association with sulfur-rich auriferous rocks. In addition to pyrite and arsenopyrite, which are the most abundant mineral phases, trace metals sulfides appear as subordinate phases. ${ }^{6-8}$ The historic mining activities developed in this region have been responsible for the release of chemicals elements into aquatic and terrestrial environments..$^{9-11}$ Large quantities of arsenic in soil (200-860 mg kg-1), sediments (22-3200 mg kg-1) and groundwater (0.4-350 $\left.\mu \mathrm{g} \mathrm{L}^{-1}\right)$ have been found in this region. ${ }^{9}$ Besides of the arsenic, quantities of Cd (5.9-6.9 $\left.\mathrm{mg} \mathrm{kg}^{-1}\right)$, Co (29.9-48.4 $\left.\mathrm{mg} \mathrm{kg}^{-1}\right)$,

*e-mail: bellato@ufv.br
$\mathrm{Cr}\left(61.7-102.5 \mathrm{mg} \mathrm{kg}^{-1}\right), \mathrm{Cu}\left(24.3-34.8 \mathrm{mg} \mathrm{kg}^{-1}\right), \mathrm{Ni}\left(22.0-69.0 \mathrm{mg} \mathrm{kg}^{-1}\right)$, $\mathrm{Pb}\left(21.9-37.1 \mathrm{mg} \mathrm{kg}^{-1}\right)$ and $\mathrm{Zn}\left(33.1-77.7 \mathrm{mg} \mathrm{kg}^{-1}\right)$ in sediments were also found in this region. ${ }^{11}$

Chemicals elements can be present in the sediments in the following chemical fractions: soluble, exchangeable, bound to organic matter, bound to iron, aluminum and manganese oxides/hydroxides, carbonates, phosphates, sulfates (or other secondary minerals), or bound to silicates. ${ }^{12,13}$ Therefore, determinations of total chemicals elements concentrations in environmental samples provide little detailed information on their potential effect as pollutants. ${ }^{14-18}$

The majority of metals present in the sediments are mainly associated with silicates and primary minerals, and therefore present less availability. ${ }^{19}$ When these chemical elements are introduced into the environment by human activity they show greater mobility, and are associated with other sediment fractions such as carbonates, organic matter, oxides, hydroxides and sulfides. ${ }^{17,20,21}$ The evaluation of these chemical fractions is possible when using sequential extraction methods. ${ }^{22-24}$ The methods most commonly used are the Tessier ${ }^{25}$ and $\mathrm{BCR},{ }^{26,27}$ proposed by the European Community Bureau of Reference.

In the BCR sequential extraction method the metal fractions are evaluated in three phases: exchangeable and bound to carbonates, reducible (bound to $\mathrm{Fe}-\mathrm{Mn}$ oxides) and oxizable (bound to organic material and sulfides). ${ }^{22}$ The last phase (residual) concerns metals bound to the mineral, which are soluble in strong acid solutions. ${ }^{20}$ The procedure simulates the mobilization and retention of these species in the natural environment, using alterations in environmental conditions such as $\mathrm{pH}$, redox potential and degradation of organic matter. ${ }^{11}$ A series of reagents is applied to the sample, increasing the extraction force in each stage in order to dissolve the metals present in different phases of the sediments. ${ }^{28}$ The advantage of using the BCR sequential extraction method is the provision of detailed information on the origin, mode of occurrence, physical-chemical and biological availability, mobilization and transport of trace metals. ${ }^{17,20,28,29,30}$

Passos et al. ${ }^{19}$ applied the BCR method in sediments collected along the Poxim River, in the Brazilian state of Sergipe. The results showed the contribution of anthropogenic sources on the mobility and toxicity 
of trace metals by means of the $\mathrm{Cd}, \mathrm{Cr}, \mathrm{Cu}, \mathrm{Ni}, \mathrm{Pb}$ and $\mathrm{Zn}$ fractionations present in the sediments. Ma et al. ${ }^{28}$ also applied the BCR sequential extraction method to evaluate the polutions levels of $\mathrm{Cr}, \mathrm{Pb}, \mathrm{Cd}, \mathrm{Co}$, $\mathrm{Cu}, \mathrm{Zn}$ and Ni metals in sediment samples of the Yellow River (China). The results showed high availability of $\mathrm{Cd}$ and $\mathrm{Co}$ due to their high concentrations in the available fractions of the sediments.

Therefore, this work presents the results of water and sediment sample analyses covering the entire length of the Carmo River $(\sim 134 \mathrm{~km})$ at two different times, before of the environmental accident at Mariana and 6 months after the accident. The second analysis was carried out in an extension that covers $\sim 22 \mathrm{~km}$ of the Carmo River where tailings mud deposition occurred, from its confluence with the Gualaxo do Norte River to its encounter with the Doce River. In the iron ore mining, several processes occur to produce richer iron ore pulp, where the tailings mud is generated containing Fe, Mn and trace elements. ${ }^{2}$ During its flow through the river, mud was mixed with the bottom material (sediment), which contains high quantities of trace elements, forming a mud layer. Thus, the objective of this study was (i) to estimate the distribution and mobility of trace elements (As, Cd, $\mathrm{Co}, \mathrm{Cr}, \mathrm{Cu}, \mathrm{Ni}, \mathrm{Pb}$ and $\mathrm{Zn}$ ) by the sequential extraction procedure in sediment samples, (ii) determine the concentrations of trace elements in the waters, and (iii) evaluate the possible environmental impacts of trace elements after spillage of the tailings mud. To the best of our knowledge, this work is unpublished in relation to the results obtained in evaluation of the distribution and mobility of trace elements, using a sequential extraction procedure in sediments collected a few months before and after the Mariana environmental accident.

\section{EXPERIMENTAL SECTION}

\section{Area under study}

The Carmo River (Figure 1), located in the state of Minas Gerais, in southeastern Brazil, is part of the Doce River Basin which has a drainage area of $83400 \mathrm{~km}^{2}$, including 222 municipalities and 461 districts. ${ }^{11}$ The Carmo River runs for a length of $134 \mathrm{~km}$, and near its headwaters are its main tributaries, the Funil Creek and Tripuí Creek, which have their sources in the municipality of Ouro Preto, located in the southern portion of the IQ. Its mouth is in the municipality of Rio Doce, at its confluence with the Piranga River where the Doce River is formed. Among its tributaries, highlighted are the Gualaxo do Norte River on its left bank and the Gualaxo do Sul River on its right bank.

\section{Sample collection and preparation}

The first collection was performed at 13 sampling points on April 8, 2015 along the Tripuí Creek (S1) and the entire length of the Carmo River (S2 to S13), obtaining both water and surface sediment samples. On April 29, 2016, six months after the environmental accident in the municipality of Mariana, a new collection was made in this same section (S1 to S13). However, for the purpose of comparison, the present study only shows the results referring to points S11 to S13, which were subject to the tailings mud and presented higher concentrations of trace elements in the water and in the sediment fractions considered as available. These samples were labeled S11a, S12a and S13a, located downstream of the confluence with the Gualaxo do Norte River which contained the mud from the Fundão dam. Figure 1 shows the location of the sampling points. Five water samples were collected at each sampling point using $1000 \mathrm{~mL}$ polytetrafluoroethylene vials, previously washed and rinsed with water. The samples were acidified to $\mathrm{pH} 2$ with nitric acid, stored in refrigerators and immediately transported. In the laboratory, the water samples were maintained refrigerated at $4{ }^{\circ} \mathrm{C}$ until analysis. At each sampling site, five sediment subsamples were collected ( 0 to $20 \mathrm{~cm}$ deep) using a plastic shovel. In the second collection the sediment samples containing the tailings mud were collected in the same manner described above, and the upper layer ( 4 $\mathrm{cm}$ ) of the sediment (mud layer) was collected separately. The mud layer was deposited throughout the river channels and was formed during the flow of tailings mud, which was mixed with the bottom material (sediment). Sediment samples and the mud layer were transferred to plastic bags and transported to the laboratory in refrigerators. They were then dried naturally, sieved $(<2 \mathrm{~mm})$, carefully ground in a porcelain mortar and homogenized.

\section{Reagents and glassware}

All reagents used were of analytical grade as well as high purity deionized water produced with a Milli-Q® system (Millipore, Bedford, MA, USA). The multielementar standard-stock solution containing $10 \mathrm{mg} \mathrm{L}^{-1}$ of As and the $\mathrm{Cd}, \mathrm{Co}, \mathrm{Cr}, \mathrm{Cu}, \mathrm{Ni}, \mathrm{Pb}$ and $\mathrm{Zn}$ metals was purchased from Perkin Elmer. Ultrapure 69.5\% (w/w) $\mathrm{HNO}_{3}$ (Fluka) was used for the preparation of all standard solutions and in the preservation and dilution of the samples. All glassware was previously decontaminated using $\mathrm{HNO}_{3}(10 \%$, v/v) for 48 hours, followed by repeated washing with ultrapure water.

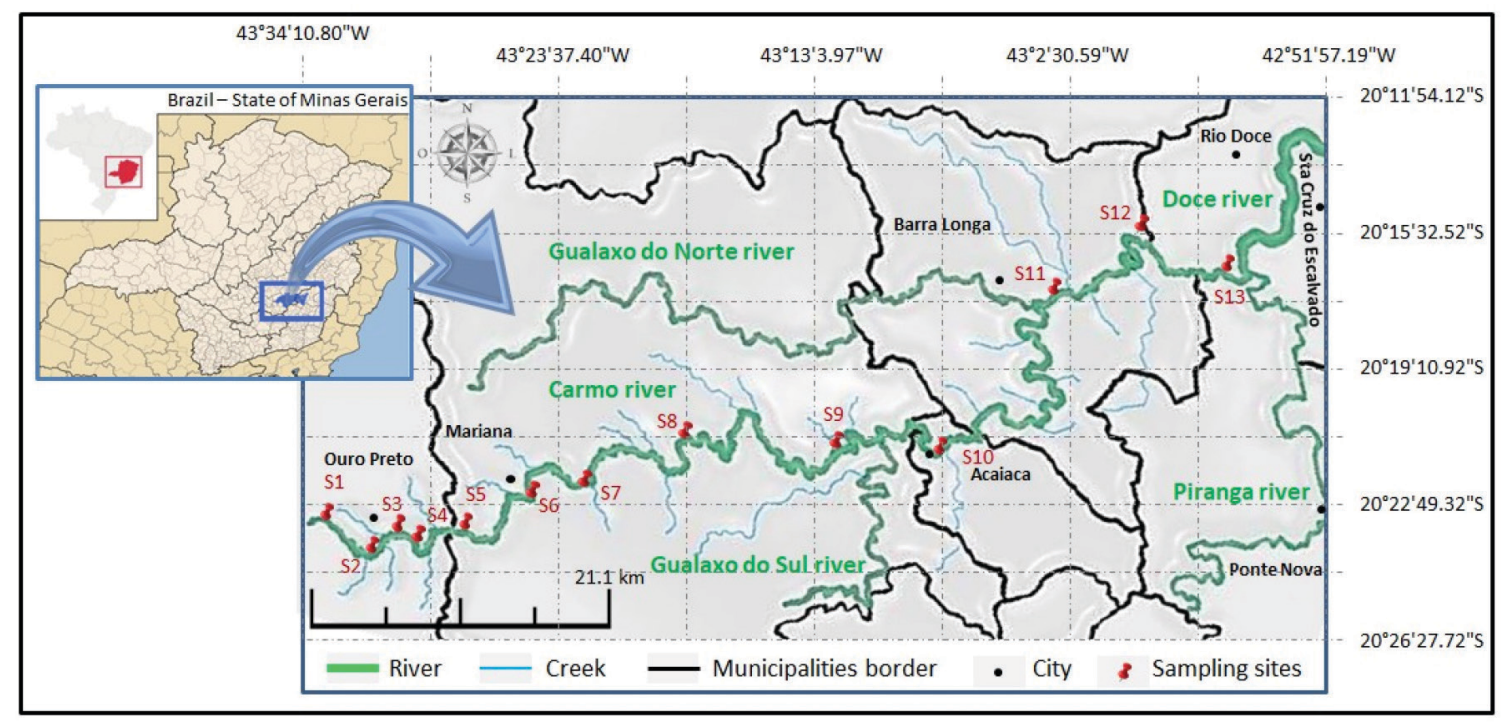

Figure 1. Locations of sampling sites in the Tripui Creek and Carmo River 


\section{Instrumentation}

The analysis of trace elements was performed using an ICP-MS (model NexION 300D) in kinetic energy discrimination (KED) mode with helium gas. The instrumental parameters of ICP-MS are presented in the Table $1 \mathrm{~S}$. All of the isotopes were selected as a function of their natural abundance and spectral interference possibility. Multielement standards were used to construct a linear calibration curve. All measurements were made by employing optimized conditions previously established. A portable $\mathrm{pH}$, redox potential and temperature meter (WTW, model 340i) and a portable dissolved oxygen (DO) meter (HANNA, model HI-9142) were used to characterize the physicochemical properties of the water samples. An analytical balance (AB204-S; METTLER TOLEDO, Brazil), a Fanen 315 centrifuge (São Paulo, Brazil) and a Milestone Ethos 1 microwave oven for closed-vessel acid digestion (Milestone, Sorisole, Italy) were used for the digestion of sediments and waters samples.

\section{Analytical procedure}

\section{Physicochemical characterization of the samples}

The redox potential, $\mathrm{pH}$, temperature and $\mathrm{DO}$ were determined using portable devices to characterize the physicochemical properties of the water samples in the field. The analysis of the trace elements in the water samples was done by adding $5 \mathrm{~mL}$ of concentrated nitric acid to $45 \mathrm{~mL}$ of water. The mixture was digested in a microwave oven, raising the temperature to $160{ }^{\circ} \mathrm{C}$ in $10 \mathrm{~min}(1,000 \mathrm{~W})$ and maintaining these conditions for $10 \mathrm{~min}$. After digestion, the aliquots were filtered into $50 \mathrm{~mL}$ flasks and the volume completed with purified water (Milli-Q). For $\mathrm{Cu}$ dissolved analysis, the samples were filtered through a cellulose acetate filter with a pore size of $0.45 \mu \mathrm{m}$. The determination of trace elements was performed using ICP-MS.

For the physicochemical characterization of the sediment samples, the procedures included $\mathrm{pH}$, cationic exchange capacity (CEC), organic matter determination, grain size analysis and X-ray diffraction. The sediment samples were sieved $(<2 \mathrm{~mm})$ and submitted to chemical and physical characterization. The $\mathrm{pH}$ was determined on a 1:2.5 soil: deionized water and $\mathrm{KCl} 1 \mathrm{~mol} \mathrm{~L}^{-1}$ ratio; the potential acidity $(\mathrm{H}+\mathrm{Al})$ was extracted with $\mathrm{Ca}(\mathrm{OAc})_{2} 0.5 \mathrm{~mol} \mathrm{~L}^{-1}$ buffered to $\mathrm{pH} 7.0$, and quantified by titration with $\mathrm{NaOH} 0.0606 \mathrm{~mol} \mathrm{~L}^{-1}$. Exchangeable $\mathrm{Ca}^{2+}, \mathrm{Mg}^{2+}$ and $\mathrm{Al}^{3+}$ were extracted with $1 \mathrm{~mol} \mathrm{~L}^{-1} \mathrm{KCl}$ and $\mathrm{Na}^{+}$and $\mathrm{K}^{+}$were extracted with Melich-1. ${ }^{31}$ The effective cation exchange capacity was calculated by sum of cations $\left(\mathrm{Ca}^{2+}, \mathrm{Mg}^{2+}\right.$, $\mathrm{Na}^{+}, \mathrm{K}^{+}$and $\mathrm{Al}^{3+}$ ) and total cation exchange capacity was estimated by the sum of bases (SB) and potential acidity. The organic matter was determined according to Walkley-Black titration method ${ }^{32}$ by wet oxidation with $\mathrm{K}_{2} \mathrm{Cr}_{2} \mathrm{O}_{7} 0.167 \mathrm{~mol} \mathrm{~L}^{-1}$ in the presence of sulfuric acid with external heating. ${ }^{33}$ The textural analysis, proportion of different grain sizes, was performed by the pipette method..$^{31,34}$

Diffractograms were obtained using powder X-ray diffraction, performed on a Panalytical X'Pert PRO diffractometer equipped with a cobalt tube (Co-K $\alpha$ radiation, $\lambda=1.790269 \AA$ ) operated at $40 \mathrm{kV}$ and $40 \mathrm{~mA}$. Scanning was performed using the step-by-step method, in the range between $4^{\circ}$ and $50^{\circ} 2 \theta$, with an increment of $0.05^{\circ}$ and time of $1 \mathrm{~s}$ per step.

\section{BCR sequential extraction procedure}

Approximately $0.8000 \mathrm{~g}$ of sediment sample sieved to $<1 \mathrm{~mm}$ were transferred to $50 \mathrm{~mL}$ centrifuge tubes and subjected to the BCR sequential extraction procedure (Table $2 \mathrm{~S}$ ) as reported by Rauret et $a l .{ }^{26} \mathrm{All}$ analyses were performed in triplicate. At the end of each step, the extracts were separated from the residual solids by centrifugation for $20 \mathrm{~min}$ at $3000 \mathrm{rpm}$. The residue was washed by the addition of 16 $\mathrm{ml}$ of water, stirring for $15 \mathrm{~min}$, and finally the resulting suspension was centrifuged. The supernatant was decanted and discarded, taking care not to discard any of the solid residues. In the fourth step, the residue was digested with aqua regia in a microwave oven, raising the temperature to $200{ }^{\circ} \mathrm{C}$ in $10 \mathrm{~min}(1,200 \mathrm{~W})$ and maintaining these conditions for $15 \mathrm{~min}$. This same digestion process was applied to $0.5000 \mathrm{~g}$ of the integral sediment (not subjected to the extraction steps) for determination of the pseudototal content. Determination of the element concentrations in each step of the BCR method and in pseudototal digestion was performed by ICP-MS. The internal standard ( Rh $5 \mu \mathrm{g} \mathrm{L}^{-1}$ ) and collision cell (He > 99.999\%) were used during the determinations to avoid interferences. The SRM 2704 reference material from the National Institute of Standards and Technology (NIST; Buffalo River Sediment) was submitted to the first three steps of the BCR extraction method. The recoverability capacity of the method was evaluated by the relationship between the sum of the content extracted in the three initial steps and the certified values. The accuracy and interference effects were evaluated using SRM 2704 reference material and addition-recovery experiments. Additionrecovery experiments were carried out using three concentration levels $\left(10 \mu \mathrm{g} \mathrm{kg}^{-1}, 25 \mu \mathrm{g} \mathrm{kg}^{-1}\right.$ and $\left.50 \mu \mathrm{g} \mathrm{kg}^{-1}\right) .{ }^{35}$ For performing these procedures, sub-samples of a randomly selected sample (S11) were digested in triplicate with aqua regia in a microwave oven maintaining the same conditions described above and subsequently analyzed by ICP-MS. Limits of detection (LOD) were calculated as 3s divided by the slope of the calibration graph, for ten reagent blanks. ${ }^{18}$ The LOD values varied from $0.01 \mu \mathrm{g} \mathrm{L}^{-1}$ (Co) to $0.09 \mu \mathrm{g} \mathrm{L}^{-1}$ ( $\mathrm{Zn}$ ) (Table 3S). These detection limits are considered acceptable for general analysis in environmental studies, ${ }^{16,30}$ and are comparable to those obtained in previous work using similar material. . $9,35,36^{-10}$

\section{RESULTS AND DISCUSSION}

\section{Sediment analysis}

\section{Physicochemical characterization}

The physical-chemical characteristics of sediment samples are presented in Table 1 . The results show the absolute predominance of sand, on average $91 \%$, in relation to the silt (4\%) and clay $(5 \%)$ fractions. Another characteristic of the sediments are the negative $\Delta \mathrm{pH}$ values, obtained by the difference between $\mathrm{pH}$ in $\mathrm{KCl}$ and $\mathrm{pH}$ in $\mathrm{H}_{2} \mathrm{O}$, which indicate a prevalence of negative charges on its surface, allowing the adsorption of trace elements. In acidic conditions, the cationic metal ions $\left(\mathrm{Cd}^{2+}, \mathrm{Co}^{2+}, \mathrm{Cr}^{2+}, \mathrm{Cu}^{2+}, \mathrm{Ni}^{2+}, \mathrm{Pb}^{2+}\right.$ and $\left.\mathrm{Zn}^{2+}\right)$ become more mobile, ${ }^{37}$ so that in areas with predominantly sandy texture under acidic conditions there is increased potential for leaching of the soluble forms of the metal compounds. ${ }^{38}$ The collected sediment samples (S1 to S13 and S11a to S13a) showed low Cation Exchange Capacity (CEC), which can be explained by the absolute prevalence of the sand fraction. However, the presence of secondary minerals such as kaolinite, gibbsite, goethite and hematite in the silt fraction, as shown in the X-ray diffraction patterns (Figure 2), gives the sediments a good trace element retention capacity.

\section{Total trace elements}

Table 2 presents the total concentrations of trace elements (As, Cd, $\mathrm{Co}, \mathrm{Cr}, \mathrm{Cu}, \mathrm{Ni}, \mathrm{Pb}$ and $\mathrm{Zn}$ ) for the 13 sediment samples. In Table 2 it is possible to observe that the total values of arsenic in the sediments (S1 to S13, S11a and S13a), as well as Cr (S2, S4, S7, S9, S10, S11 and S13, S11a and S13a) and $\mathrm{Ni}$ (S1, S3, S5, S7, S9, S10, S13, S13a), are above Level 2 of the CONAMA Resolution 454/12 ${ }^{39}$ (value above which there is a higher probability of adverse effects on biota). 
Table 1. Characterization of the sediments collected along the Tripuí Creek and Carmo River

\begin{tabular}{|c|c|c|c|c|c|c|c|c|c|c|c|}
\hline \multirow{2}{*}{$\begin{array}{l}\text { Sampling } \\
\text { Sites }\end{array}$} & \multirow[b]{2}{*}{ Coordinates $(\mathrm{S} / \mathrm{W})$} & \multirow{2}{*}{$\begin{array}{c}\text { Organic } \\
\text { Matter } \\
\left(\mathrm{mg} \mathrm{g}^{-1}\right)\end{array}$} & \multicolumn{2}{|c|}{$\mathrm{pH}$} & \multirow[b]{2}{*}{$\Delta \mathrm{pH}$} & \multirow{2}{*}{$\begin{array}{l}\text { Total } \\
\text { CEC }^{\text {a }}\end{array}$} & \multirow{2}{*}{$\begin{array}{c}\text { Effective } \\
\text { CEC }^{a}\end{array}$} & \multicolumn{4}{|c|}{ Granulometry (\%) } \\
\hline & & & $\mathrm{H}_{2} \mathrm{O}$ & $\mathrm{KCl}$ & & & & $\begin{array}{c}\text { Coarse } \\
\text { sand }\end{array}$ & $\begin{array}{l}\text { Fine } \\
\text { sand }\end{array}$ & Silt & Clay \\
\hline$\overline{S 1}$ & $20^{\circ} 23^{\prime} 03.02^{\prime \prime} / 43^{\circ} 32^{\prime} 53.33^{\prime \prime}$ & 5.00 & 5.24 & 5.79 & -0.55 & 1.72 & 1.22 & 55 & 37 & 4 & 4 \\
\hline S2 & $20^{\circ} 24^{\prime} 02.52^{\prime \prime} / 43^{\circ} 31^{\prime} 32.61^{\prime \prime}$ & 2.50 & 5.53 & 5.93 & -0.40 & 1.37 & 1.07 & 79 & 12 & 4 & 5 \\
\hline S3 & $20^{\circ} 23^{\prime} 25.11^{\prime \prime} / 43^{\circ} 30^{\prime} 26.61^{\prime \prime}$ & 5.00 & 5.40 & 6.11 & -0.71 & 1.89 & 1.39 & 74 & 15 & 5 & 6 \\
\hline S4 & $20^{\circ} 23^{\prime} 54.62^{\prime \prime} / 43^{\circ} 29^{\prime} 50.01^{\prime \prime}$ & 9.83 & 5.33 & 6.09 & -0.76 & 1.42 & 1.12 & 80 & 12 & 4 & 4 \\
\hline S5 & $20^{\circ} 23^{\prime} 39.00^{\prime \prime} / 43^{\circ} 26^{\prime} 34.72^{\prime \prime}$ & 9.40 & 5.36 & 6.73 & -1.38 & 1.60 & 1.30 & 85 & 7 & 3 & 5 \\
\hline S6 & $20^{\circ} 22^{\prime} 31.41^{\prime \prime} / 43^{\circ} 24^{\prime} 53.11^{\prime \prime}$ & 6.30 & 5.71 & 6.63 & -0.92 & 2.78 & 2.48 & 54 & 32 & 8 & 6 \\
\hline S7 & $20^{\circ} 22^{\prime} 06.91^{\prime \prime} / 43^{\circ} 22^{\prime} 31.91^{\prime \prime}$ & 3.10 & 5.75 & 6.35 & -0.60 & 1.91 & 1.41 & 81 & 10 & 3 & 6 \\
\hline S8 & $20^{\circ} 21^{\prime} 00.32^{\prime \prime} / 43^{\circ} 18^{\prime} 39.13^{\prime \prime}$ & 3.10 & 5.73 & 6.25 & -0.52 & 1.33 & 1.03 & 77 & 15 & 3 & 5 \\
\hline S9 & $20^{\circ} 21^{\prime} 30.52^{\prime \prime} / 43^{\circ} 12^{\prime} 09.71^{\prime \prime}$ & 3.10 & 5.80 & 6.27 & -0.47 & 1.71 & 1.41 & 67 & 29 & 1 & 3 \\
\hline S10 & $20^{\circ} 21^{\prime} 43.43^{\prime \prime} / 43^{\circ} 08^{\prime} 31.15^{\prime \prime}$ & 15.70 & 5.66 & 6.23 & -0.57 & 3.78 & 3.08 & 48 & 24 & 16 & 12 \\
\hline S11 & $20^{\circ} 17^{\prime} 09.02^{\prime \prime} / 43^{\circ} 03^{\prime} 36.71^{\prime \prime}$ & 1.30 & 5.85 & 6.21 & -0.36 & 1.59 & 0.89 & 55 & 35 & 5 & 5 \\
\hline S12 & $20^{\circ} 15^{\prime} 19.87^{\prime \prime} / 42^{\circ} 59^{\prime} 30.88^{\prime \prime}$ & 1.30 & 5.89 & 6.10 & -0.21 & 1.45 & 1.15 & 77 & 18 & 2 & 3 \\
\hline S13 & $20^{\circ} 16^{\prime} 46.83^{\prime \prime} / 42^{\circ} 55^{\prime} 30.08^{\prime \prime}$ & 1.30 & 6.06 & 6.32 & -0.26 & 1.22 & 0.92 & 92 & 3 & 1 & 4 \\
\hline S11a & $20^{\circ} 17^{\prime} 09.02^{\prime \prime} / 43^{\circ} 03^{\prime} 36.71^{\prime \prime}$ & 1.21 & 5.91 & 6.49 & -0.58 & 1.64 & 0.94 & 49 & 38 & 7 & 6 \\
\hline $\mathrm{S} 12 \mathrm{a}$ & $20^{\circ} 15^{\prime} 19.87^{\prime \prime} / 42^{\circ} 59^{\prime} 30.88^{\prime \prime}$ & 0.98 & 5.93 & 6.46 & -0.53 & 1.49 & 0.99 & 55 & 34 & 5 & 6 \\
\hline S13a & $20^{\circ} 16^{\prime} 46.83^{\prime \prime} / 42^{\circ} 55^{\prime} 30.08^{\prime \prime}$ & 0.73 & 6.15 & 6.53 & -0.38 & 1.25 & 0.85 & 41 & 39 & 12 & 8 \\
\hline
\end{tabular}

${ }^{a} \mathrm{CEC}$ cation exchange capacity

The results indicate that these elements were already deposited in the bed of the Carmo River before the arrival of material from the tailings dam. The presence of arsenic may be related to the development of gold mining in the region for centuries, and although much of it is deactivated, there is still activity on the Carmo River. Furthermore, these sampling points are located along the Carmo River, which drains the cities of Ouro Preto and Mariana, and also drains the Passagem Mine (municipality of Mariana) that is geologically rich in arsenic minerals. ${ }^{11}$

Segura et al. ${ }^{2}$ collected samples of tailings mud 23 days after rupture of the dam of Fundão (November 28, 2015), where it was determined that Fe ( 20000 to $\left.30000 \mathrm{mg} \mathrm{kg}^{-1}\right)$ and $\mathrm{Mn}(\sim 100$ to $\left.300 \mathrm{mg} \mathrm{kg}^{-1}\right)$ were the main elements, and trace elements ( $\mathrm{Pb}, \mathrm{As}, \mathrm{Sr}$, $\mathrm{Zn}, \mathrm{Cu}, \mathrm{Ni}$ and $\mathrm{Co}$ ) with concentrations in the slurry ranging from $<0.46 \mathrm{mg} \mathrm{kg}^{-1}$ to $\sim 6.5 \mathrm{mg} \mathrm{kg}^{-1}$. During its flow through the river the mud was mixed with the bottom material (sediment), which contains high quantities of trace elements (Table 2), forming a mud layer. At collection points S11a to S13a, the tailings layer had a thickness of $\sim 4 \mathrm{~cm}$, however the thickness of the mud layer may vary according to water flow along the entire length of the river. Thus, the mud layer covering the entire length of the river bed had, due to sediment incorporation, presented increased concentration of trace elements, as shown in Table 2 .

\section{Fractionation}

Figure 3 shows the results obtained for the fractionation of trace elements in the sediment samples collected from the Tripuí Creek (S1) and the Carmo River (S2 to S13). The relative proportions of As in the acid soluble fraction (F1) were generally low $(<10 \%)$. Concentrations of Cd (S1, S5, S6, S8-S13), Cu (S8), Pb (S9) and Zn $(\mathrm{S} 1, \mathrm{~S} 4)$ were $>10 \%$ in the F1 fraction. Extraction of trace elements in the F1 fraction (exchangeable and bound to carbonates) can be mainly attributed to its association with carbonates present in the sediments, due to the extensive alteration in carbonates in the ore deposits of this region. ${ }^{10}$ Metals present in the F1 fraction are considered to be more weakly bound to the sediments, being able to equilibrate with the aqueous phase and therefore become more readily available. ${ }^{36,40-43}$

In relation to the reducible fraction $(\mathrm{F} 2)$, it can be observed that $\mathrm{Ni}, \mathrm{Co}$ and $\mathrm{Pb}$ have a strong affinity with this fraction, which is also potentially available. On average, $37.2 \%$ of $\mathrm{Ni}, 36.1 \%$ of $\mathrm{Co}$ and $30.5 \%$ of $\mathrm{Pb}$ were found in this fraction, ranges of $9.5-88 \%$, $14.1-54.4 \%$ and $15.1-51.5 \%$, respectively, between sampling points (S1 to S13). Secondary minerals in the silt fraction containing $\mathrm{Fe}$ and $\mathrm{Al}$ hydroxides (Figure 2) present large surface adsorption areas, increasing the retention of trace elements in this fraction. ${ }^{19,43}$ These adsorbed metals (linked to Fe-Mn oxides) have the potential to be transferred to the aquatic environment, by means of changes in the redox potential or $\mathrm{pH}$ of the medium. ${ }^{11,13,44,45}$

In the oxidizable fraction (F3), relatively high values are observed for $\mathrm{Cr}$ and $\mathrm{Cu}$. On average, $29.5 \%$ of $\mathrm{Cr}$ and $25.0 \%$ of $\mathrm{Cu}$ were found in this fraction, ranging from $11.7-60.1 \%$ for $\mathrm{Cr}$ and $8.2-42.6 \%$ for $\mathrm{Cu}$ among the sampling points ( $\mathrm{S} 1$ to $\mathrm{S} 13)$. The metals $(\mathrm{Cu}$ and $\mathrm{Cr}$ ) are strongly complexed by organic matter (humic substances) in the sediments, being released after degradation of organic matter or oxidation of sulphides to sulphates. ${ }^{17,19,45}$ Furthermore, $\mathrm{Cu}$ is commonly found to be strongly bound to organic matter, due to the high stability constant of organic copper compounds. ${ }^{28}$ The largest quantities of As found in the oxidizable fraction (F3) of the sediments at sampling sites S6 and S7 (Figure 3) may be related to contribution of the oxidative dissolution of arsenic-rich sulfide minerals from the Passagem Mine (municipality of Mariana ), the oldest and most important gold mine in the region located upstream of S6 and S7. ${ }^{10,11}$

The residual fraction $(\mathrm{R})$ corresponds to As and metals occluded in non-silicated minerals extracted during the final step of the BCR method by means of digestion with aqua regia. The $\mathrm{R}$ fraction presented the highest levels of trace elements, except for $\mathrm{Cd}$. In the residual fraction the following concentration intervals were obtained for As (70.5-97.2\%), Zn (17.7-95\%), Pb (37.2-93.1\%), Cu (25.3-85.9\%), Co (34.6-81.9\%), Cr(28.6-78.0\%) and $\mathrm{Ni}(17.6-77.5 \%)$ between sampling points ( $\mathrm{S} 1$ to S13). The large quantity of these elements in this fraction shows that they are linked to the crystalline network of the secondary minerals and are not easily remobilized to the aquatic environment. ${ }^{13,19,28,45-47}$

Figure 3 also shows that there was a modification in the fractionation profile of trace elements (S11 to S13) after the Mariana environmental accident with deposition of the mud layer (S11a to S13a). Modification in the fractionation profile can be better observed in Table 3 , where the average values between sampling points are presented for 


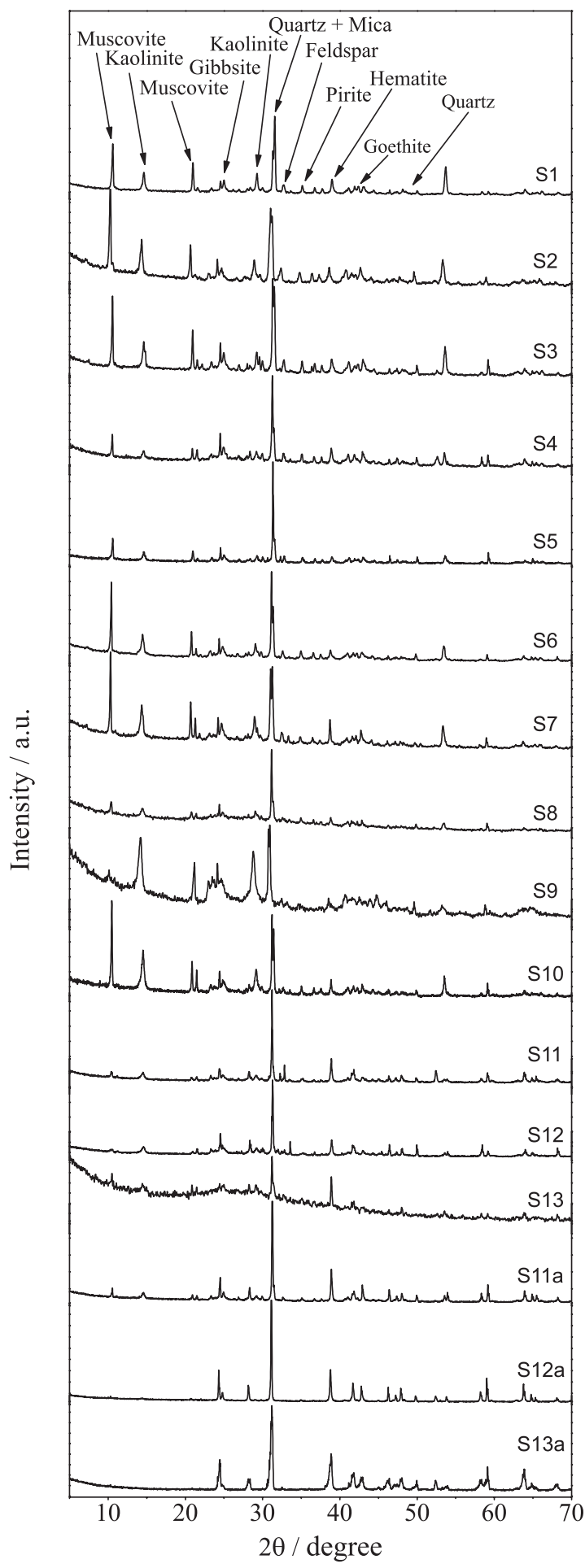

Figure 2. X-ray diffraction spectra from silt fraction of the sediments samples. Sampling sites $S 1$ to S13 and S11a to S13a

the concentration of each element in the different sediment fractions. Before the Mariana environmental accident, the average percentage of extracted metals in the available fractions $(\mathrm{F} 1+\mathrm{F} 2+\mathrm{F} 3)$ of the sediments, for the last 3 sampling points ( $\mathrm{S} 11$ to $\mathrm{S} 13$ ), presented a decreasing order of availability: $\mathrm{Cd}(65 \%)>\mathrm{Cu}(54 \%)>\mathrm{Ni}(53 \%)>$ $\mathrm{Co}(49 \%)>\mathrm{Cr}(44 \%)>\mathrm{Pb}(38 \%)>\mathrm{Zn}(13 \%)>\mathrm{As}(5 \%)$.

After the Mariana environmental accident, the average percentage of extracted metals in the available fractions followed the same decreasing order of availability, but there was an increase in the quantity of elements in these fractions: $\mathrm{Cd}(78 \%)>\mathrm{Cu}(65 \%)>\mathrm{Ni}(57 \%)>\mathrm{Co}$
$(54 \%)>\mathrm{Cr}(53 \%)>\mathrm{Pb}(45 \%)>\mathrm{Zn}(32 \%)>\mathrm{As}(25 \%)$. The results show that deposition of the mud layer on the sediment caused a change in the availability of trace elements, making them more available. The sequential extraction procedure applied to the mud layer (Table 4) also showed large quantities of trace elements in available fractions, which justifies the increased availability of these elements in the aquatic environment after deposition of the mud layer on the sediment samples.

Pseudototal digestion of the sediment samples (Table 2) and the mud layer (Table 4) with aqua regia is used as a tool for internal evaluation of the recoverability of the method. The relationship between the sum of the quantities obtained from the sequential extraction (including the residual fraction) and the pseudototal content allowed for calculation of the recovery. The results showed acceptable recovery percentages for the BCR method, ranging from $84 \%$ to $106 \%$ for the sediment samples and from $83 \%$ to $97 \%$ for the mud layer. Application of this method to the SRM 2704 NIST reference material also showed satisfactory recoveries in relation to the certified values: As (95\%), Cd (86\%), Co (87\%), Cr (83\%), Cu (102\%), Ni (108\%), $\mathrm{Pb}(107 \%)$ and $\mathrm{Zn}(95 \%)$. Very good agreement was also achieved, with no significant differences between values at the $95 \%$ confidence level. Recoveries higher than $97 \%$ and less than $105 \%$ were obtained in the addition-recovery experiments carried out in the sample S11 using the three concentration levels $\left(10 \mu \mathrm{g} \mathrm{kg}^{-1}, 25 \mu \mathrm{g} \mathrm{kg}^{-1}\right.$ and $50 \mu \mathrm{g} \mathrm{kg}^{-1}$ ). These values reflect the efficiency of the method, as well as the precision of the results, and are considered satisfactory given the complex nature of the sediment matrix..$^{19,35,36}$

\section{Water analysis}

Table 5 shows the total As concentration and physical-chemical parameters of the water samples collected in the Tripuí Creek (S1) and the Carmo River before (S2-S13) and after (S11a-S13a) deposition of mud on the sediment. The accuracy of the results of the trace elements analysis in water samples were determined in a spiked of standard multielement solution. Spike recoveries ranged from 88 to $104 \%$.

The in situ $\mathrm{pH}$ values obtained for the sampling points $\mathrm{S} 1$ to $\mathrm{S} 13$ and S11a to S13a ranged from 6.8 to 7.8. These results are within normal limits, i.e., do not violate the limits established in legislation (range 6 to 9), which are adequate values for the maintenance of aquatic life..$^{48}$ It can also be observed that even after deposition of the mud layer (S11a to S13a), the $\mathrm{pH}$ values remained within a normal range. In relation to dissolved oxygen, all results were in compliance with the limit established by Brazilian environmental legislation (values greater than $5 \mathrm{mg} \mathrm{L}^{-1} \mathrm{O}_{2}$ ). ${ }^{48}$

All samples presented concentrations of As $>10 \mu \mathrm{g} \mathrm{L}^{-1}$, the maximum limit established by Brazilian environmental legislation ${ }^{48}$ for water destined for human consumption. The values of total As are in agreement with the range observed in other regions of the $\mathrm{IQ}^{10,11}$ and with those verified by previous studies on As concentrations in surface water samples of the Carmo River. ${ }^{11}$ The SEMAD-IGAM ${ }^{49}$ and the Company of Research on Mineral Resources ${ }^{50}$ performed a water analysis in November and December of 2015, shortly after the environmental accident, at a sampling point at the confluence of the Gualaxo do Norte River with the Carmo River, approximately corresponding to sampling point S11. We verified that the results of the present work are consistent with respect to trace elements, except for the difference found for As, which in our case was slightly greater than $10 \mu \mathrm{g} \mathrm{L}^{-1}$.

The difference found in the results for As may be due to the physico-chemical changes that occurred in water samples on the day of collection. However, after deposition of the mud layer on the Carmo River sediment, there was an increase in the total As concentration in water samples (S11a-S13a). As can be verified in the results from 
Table 2. Trace elements in sediment sample from the Tripuí Creek and Carmo River (mean \pm standard deviation, n=3)

\begin{tabular}{|c|c|c|c|c|c|c|c|c|}
\hline \multirow{2}{*}{ Sampling Sites } & \multicolumn{8}{|c|}{ Concentration of trace elements in $\mathrm{mg} \mathrm{kg}^{-1}$} \\
\hline & As & $\mathrm{Cd}$ & Co & $\mathrm{Cr}$ & $\mathrm{Cu}$ & $\mathrm{Ni}$ & $\mathrm{Pb}$ & $\mathrm{Zn}$ \\
\hline CONAMA 454/2012a & 17 & 3.5 & --- & 90 & 197 & 35.9 & 91.3 & 315 \\
\hline S1 & $48.1 \pm 1.3$ & $0.13 \pm 0.04$ & $33.1 \pm 0.5$ & $58.3 \pm 4.5$ & $24.2 \pm 1.1$ & $51.4 \pm 1.0$ & $5.3 \pm 0.2$ & $8.0 \pm 1.3$ \\
\hline S2 & $71.6 \pm 1.0$ & $0.15 \pm 0.02$ & $21.1 \pm 0.8$ & $135.5 \pm 3.8$ & $18.1 \pm 1.1$ & $17.5 \pm 0.6$ & $10.5 \pm 1.0$ & $5.6 \pm 0.5$ \\
\hline S3 & $71.1 \pm 1.3$ & $0.16 \pm 0.06$ & $42.4 \pm 3.0$ & $67.9 \pm 9.3$ & $35.2 \pm 1.5$ & $44.5 \pm 1.1$ & $14.3 \pm 4.1$ & $41.4 \pm 7.1$ \\
\hline S4 & $187.4 \pm 5.8$ & $0.17 \pm 0.02$ & $19.0 \pm 0.2$ & $102.8 \pm 3.6$ & $19.7 \pm 5.9$ & $13.0 \pm 0.2$ & $8.0 \pm 0.3$ & $12.2 \pm 1.0$ \\
\hline S5 & $105.8 \pm 5.0$ & $0.16 \pm 0.01$ & $18.4 \pm 0.2$ & $50.7 \pm 0.1$ & $13.4 \pm 0.7$ & $47.3 \pm 0.4$ & $9.4 \pm 0.3$ & $47.3 \pm 0.9$ \\
\hline S6 & $301.9 \pm 9.0$ & $0.21 \pm 0.04$ & $18.7 \pm 0.6$ & $65.9 \pm 1.6$ & $22.8 \pm 2.0$ & $30.5 \pm 0.1$ & $12.0 \pm 0.3$ & $49.3 \pm 1.0$ \\
\hline S7 & $216.9 \pm 1.2$ & $0.06 \pm 0.01$ & $22.4 \pm 1.2$ & $115.4 \pm 1.2$ & $19.4 \pm 1.1$ & $37.9 \pm 0.9$ & $58.6 \pm 0.9$ & $12.1 \pm 0.8$ \\
\hline S8 & $200.2 \pm 1.6$ & $0.03 \pm 0.01$ & $12.5 \pm 0.8$ & $48.2 \pm 1.1$ & $40.6 \pm 0.4$ & $26.4 \pm 1.5$ & $5.8 \pm 0.2$ & $32.0 \pm 2.1$ \\
\hline S9 & $28.6 \pm 0.5$ & $0.18 \pm 0.02$ & $13.1 \pm 0.6$ & $214.2 \pm 1.9$ & $14.2 \pm 0.3$ & $39.2 \pm 1.3$ & $6.4 \pm 0.5$ & $64.7 \pm 3.1$ \\
\hline S10 & $128.7 \pm 6.7$ & $0.06 \pm 0.02$ & $17.8 \pm 0.9$ & $135.4 \pm 2.0$ & $28.4 \pm 0.7$ & $64.8 \pm 0.4$ & $7.8 \pm 0.6$ & $73.1 \pm 6.5$ \\
\hline S11 & $234.3 \pm 2.6$ & $0.10 \pm 0.01$ & $14.7 \pm 0.7$ & $133.9 \pm 1.0$ & $14.6 \pm 0.9$ & $22.7 \pm 0.6$ & $3.0 \pm 0.7$ & $64.3 \pm 1.0$ \\
\hline $\mathrm{S} 12$ & $75.5 \pm 2.0$ & $0.20 \pm 0.01$ & $10.5 \pm 0.6$ & $58.8 \pm 0.6$ & $21.2 \pm 1.1$ & $7.3 \pm 0.3$ & $3.2 \pm 1.2$ & $19.8 \pm 0.7$ \\
\hline S13 & $125.8 \pm 1.1$ & $0.15 \pm 0.03$ & $37.4 \pm 0.8$ & $117.0 \pm 5.1$ & $36.2 \pm 1.0$ & $47.4 \pm 0.6$ & $10.9 \pm 0.7$ & $28.2 \pm 0.2$ \\
\hline S11a & $249.1 \pm 1.5$ & $0.15 \pm 0.01$ & $18.5 \pm 0.2$ & $144.9 \pm 2.4$ & $17.8 \pm 0.6$ & $26.1 \pm 0.8$ & $5.1 \pm 0.5$ & $78.4 \pm 0.6$ \\
\hline S12a & $83.9 \pm 0.5$ & $0.20 \pm 0.02$ & $14.9 \pm 0.8$ & $75.0 \pm 0.7$ & $20.6 \pm 2.3$ & $9.1 \pm 0.6$ & $4.7 \pm 0.1$ & $28.0 \pm 0.8$ \\
\hline S13a & $145.3 \pm 1.1$ & $0.11 \pm 0.01$ & $41.6 \pm 0.5$ & $110.8 \pm 2.2$ & $47.0 \pm 1.2$ & $53.7 \pm 0.6$ & $12.5 \pm 0.1$ & $37.6 \pm 0.6$ \\
\hline Mud Layer ${ }^{\mathrm{b}}$ & $34.9 \pm 0.3$ & $0.25 \pm 0.05$ & $7.7 \pm 0.3$ & $23.3 \pm 1.0$ & $8.2 \pm 0.3$ & $6.5 \pm 0.2$ & $14.5 \pm 0.5$ & $48.5 \pm 0.1$ \\
\hline
\end{tabular}

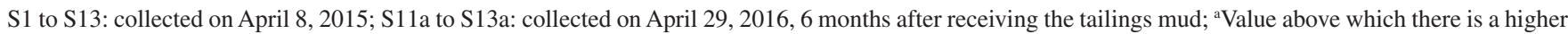
probability of adverse effects to biota, Level 2 (CONAMA 2012); ${ }^{b}$ Moisture of sediment and mud.
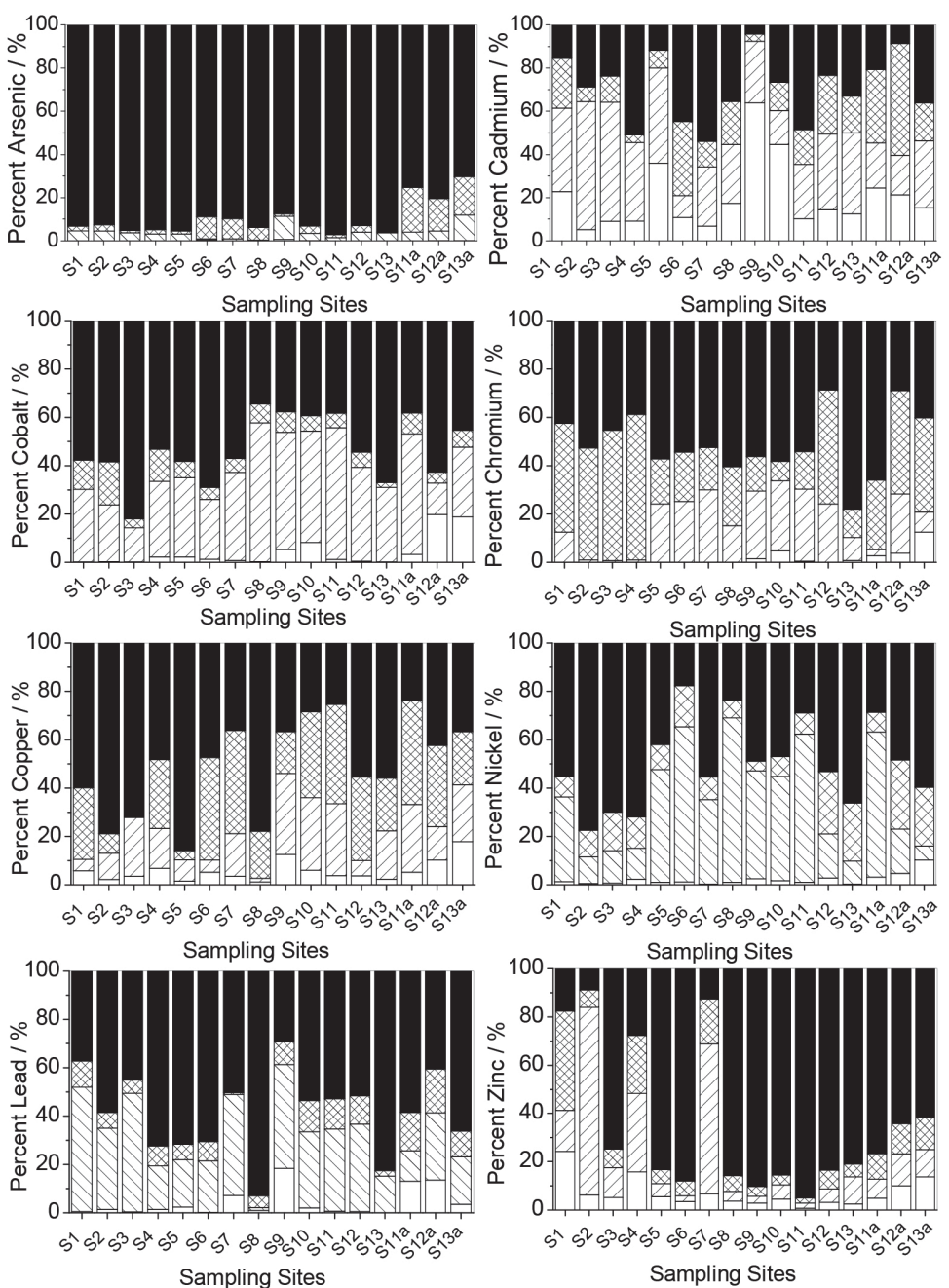

$\square \%$ F1 DZA \% F2 \% F3

Figure 3. Fractionation of $\mathrm{As}, \mathrm{Cd}, \mathrm{Co}, \mathrm{Cr}, \mathrm{Cu}, \mathrm{Ni}, \mathrm{Pb}$ e $\mathrm{Zn}$ in sediments from the Tripui Creek and Carmo River 
Table 3. Results obtained for average concentrations of $\mathrm{As}, \mathrm{Cd}, \mathrm{Co}, \mathrm{Cr}, \mathrm{Cu}, \mathrm{Ni}, \mathrm{Pb}$ and $\mathrm{Zn}$ in each fraction, $\sum \mathrm{F} 1+\mathrm{F} 2+\mathrm{F} 3+\mathrm{R}$ and $\sum \mathrm{F} 1+\mathrm{F} 2+\mathrm{F} 3$ for surface sediments from the Tripuí Creek and Carmo River (mean \pm standard deviation, $\mathrm{n}=3$ )

\begin{tabular}{|c|c|c|c|c|c|c|}
\hline & & & & & & \\
\hline & $\begin{array}{c}\mathrm{F} 1 \\
\left(\mathrm{mg} \mathrm{kg}^{-1}\right)\end{array}$ & $\begin{array}{c}\mathrm{F} 2 \\
\left(\mathrm{mg} \mathrm{kg}^{-1}\right)\end{array}$ & $\begin{array}{c}\mathrm{F} 3 \\
\left(\mathrm{mg} \mathrm{kg}^{-1}\right)\end{array}$ & $\begin{array}{l}\text { Residual } \\
\left(\mathrm{mg} \mathrm{kg}^{-1}\right)\end{array}$ & $\begin{array}{c}2[\mathrm{FI}+\mathrm{F} 2+\mathrm{FJ}+\mathrm{K}] \\
\left(\mathrm{mg} \mathrm{kg}^{-1}\right)\end{array}$ & $\begin{array}{l}+\mathrm{F} 2 \\
(\%)\end{array}$ \\
\hline $\mathrm{As}^{\mathrm{a}}$ & $0.25 \pm 0.34$ & $3.7 \pm 1.2$ & $13.2 \pm 9.7$ & $124.2 \pm 57.1$ & $141.4 \pm 57.9$ & $12 \pm 2$ \\
\hline $\mathrm{As}^{\mathrm{b}}$ & $0.02 \pm 0.01$ & $3.8 \pm 0.7$ & $2.1 \pm 1.0$ & $148.9 \pm 65.7$ & $154.9 \pm 55.1$ & $5 \pm 2$ \\
\hline$A s^{c}$ & $0.19 \pm 0.02$ & $7.1 \pm 1.6$ & $14.3 \pm 3.2$ & $131.2 \pm 45.2$ & $152.8 \pm 35.8$ & $14 \pm 4$ \\
\hline $\mathrm{Cd}^{\mathrm{a}}$ & $0.02 \pm 0.02$ & $0.04 \pm 0.02$ & $0.01 \pm 0.01$ & $0.03 \pm 0.02$ & $0.10 \pm 0.04$ & $70 \pm 7$ \\
\hline $\mathrm{Cd}^{\mathrm{b}}$ & $0.02 \pm 0.01$ & $0.05 \pm 0.01$ & $0.03 \pm 0.01$ & $0.05 \pm 0.01$ & $0.15 \pm 0.01$ & $65 \pm 9$ \\
\hline $\mathrm{Cd}^{\mathrm{c}}$ & $0.03 \pm 0.01$ & $0.03 \pm 0.01$ & $0.06 \pm 0.03$ & $0.04 \pm 0.01$ & $0.16 \pm 0.03$ & $72 \pm 8$ \\
\hline $\mathrm{Co}^{\mathrm{a}}$ & $0.30 \pm 0.26$ & $6.9 \pm 1.4$ & $1.7 \pm 0.9$ & $12.6 \pm 6.4$ & $21.5 \pm 6.6$ & $41 \pm 3$ \\
\hline $\mathrm{Co}^{\mathrm{b}}$ & $0.09 \pm 0.26$ & $7.7 \pm 2.5$ & $0.77 \pm 0.07$ & $12.1 \pm 8.6$ & $28.8 \pm 4.8$ & $47 \pm 9$ \\
\hline $\mathrm{Co}^{\mathrm{c}}$ & $3.8 \pm 2.7$ & $7.7 \pm 3.9$ & $1.7 \pm 0.8$ & $11.8 \pm 4.7$ & $25.0 \pm 3.9$ & $51 \pm 9$ \\
\hline $\mathrm{Cr}^{\mathrm{a}}$ & $0.85 \pm 0.21$ & $19.7 \pm 1.5$ & $26.5 \pm 13.1$ & $53.1 \pm 24.5$ & $100.2 \pm 27.8$ & $47 \pm 12$ \\
\hline $\mathrm{Cr}^{\mathrm{b}}$ & $0.51 \pm 0.34$ & $21.8 \pm 12.1$ & $20.7 \pm 4.7$ & $60.3 \pm 29.0$ & $103.2 \pm 17.2$ & $46 \pm 16$ \\
\hline $\mathrm{Cr}^{\mathrm{c}}$ & $6.8 \pm 4.7$ & $5.5 \pm 2.5$ & $39.0 \pm 4.6$ & $59.0 \pm 24.4$ & $110.3 \pm 7.7$ & $48 \pm 8$ \\
\hline $\mathrm{Cu}^{\mathrm{a}}$ & $0.96 \pm 0.36$ & $4.1 \pm 2.7$ & $5.7 \pm 2.4$ & $19.6 \pm 4.5$ & $30.3 \pm 5.8$ & $35 \pm 6$ \\
\hline $\mathrm{Cu}^{\mathrm{b}}$ & $0.73 \pm 0.12$ & $4.3 \pm 2.0$ & $7.1 \pm 0.7$ & $11.9 \pm 5.6$ & $24.0 \pm 4.5$ & $54 \pm 13$ \\
\hline $\mathrm{Cu}^{\mathrm{c}}$ & $3.8 \pm 2.0$ & $6.3 \pm 3.2$ & $8.9 \pm 1.3$ & $9.5 \pm 4.2$ & $28.5 \pm 2.1$ & $69 \pm 11$ \\
\hline $\mathrm{Ni}^{\mathrm{a}}$ & $0.38 \pm 0.20$ & $12.4 \pm 7.7$ & $4.1 \pm 2.2$ & $17.1 \pm 9.3$ & $34.0 \pm 12.2$ & $50 \pm 8$ \\
\hline $\mathrm{Ni}^{\mathrm{b}}$ & $0.21 \pm 0.01$ & $6.6 \pm 4.9$ & $5.1 \pm 3.2$ & $13.9 \pm 6.6$ & $25.8 \pm 3.8$ & $51 \pm 14$ \\
\hline $\mathrm{Ni}^{\mathrm{c}}$ & $2.2 \pm 1.1$ & $6.8 \pm 2.8$ & $5.9 \pm 2.7$ & $14.6 \pm 10.4$ & $29.6 \pm 3.2$ & $55 \pm 11$ \\
\hline $\mathrm{Pb}^{\mathrm{a}}$ & $0.47 \pm 0.28$ & $4.1 \pm 1.8$ & $0.58 \pm 0.24$ & $6.7 \pm 4.1$ & $11.8 \pm 4.5$ & $44 \pm 5$ \\
\hline $\mathrm{Pb}^{\mathrm{b}}$ & $0.12 \pm 0.07$ & $1.3 \pm 0.3$ & $0.33 \pm 0.04$ & $4.1 \pm 3.3$ & $5.8 \pm 1.3$ & $38 \pm 13$ \\
\hline $\mathrm{Pb}^{\mathrm{c}}$ & $0.60 \pm 0.05$ & $1.6 \pm 0.8$ & $1.1 \pm 0.3$ & $4.8 \pm 3.2$ & $8.1 \pm 1.4$ & $45 \pm 10$ \\
\hline $\mathrm{Zn}^{\mathrm{a}}$ & $1.4 \pm 0.7$ & $3.0 \pm 1.7$ & $2.2 \pm 0.7$ & $28.0 \pm 19.1$ & $34.6 \pm 19.2$ & $19 \pm 3$ \\
\hline $\mathrm{Zn}^{\mathrm{b}}$ & $0.59 \pm 0.10$ & $1.9 \pm 0.9$ & $1.5 \pm 0.1$ & $33.5 \pm 18.4$ & $37.5 \pm 12.1$ & $13 \pm 6$ \\
\hline $\mathrm{Zn}^{\mathrm{c}}$ & $3.9 \pm 0.8$ & $3.7 \pm 1.0$ & $6.3 \pm 3.4$ & $34.1 \pm 11.3$ & $48.1 \pm 16.1$ & $29 \pm 7$ \\
\hline
\end{tabular}

${ }^{\mathrm{a}}$ Mean of the 13 points (S1 to S13); ${ }^{\mathrm{b}}$ Average of the last 3 points (S11 to S13); ${ }^{\mathrm{c} A v e r a g e ~ o f ~ t h e ~ l a s t ~} 3$ points after the Mariana environmental accident (S11a to S13a).

Table 4. As, $\mathrm{Cd}, \mathrm{Co}, \mathrm{Cr}, \mathrm{Cu}, \mathrm{Ni}, \mathrm{Pb}$ and $\mathrm{Zn}$ in each fraction, $\sum \mathrm{F} 1+\mathrm{F} 2+\mathrm{F} 3+\mathrm{R}$ and $\sum \mathrm{F} 1+\mathrm{F} 2+\mathrm{F} 3$ for the Mud Layer (mean \pm standard deviation, $\mathrm{n}=3$ )

\begin{tabular}{|c|c|c|c|c|c|c|}
\hline & \multicolumn{6}{|c|}{ Mud Layer } \\
\hline & \multicolumn{4}{|c|}{ Steps } & \multirow{2}{*}{$\begin{array}{c}\sum[\mathrm{F} 1+\mathrm{F} 2+\mathrm{F} 3+\mathrm{R}] \\
\left(\mathrm{mg} \mathrm{kg}^{-1}\right)\end{array}$} & \multirow{2}{*}{$\begin{array}{c}\sum[\mathrm{F} 1+\mathrm{F} 2+\mathrm{F} 3] \\
(\%)\end{array}$} \\
\hline & $\begin{array}{c}\mathrm{F} 1 \\
\left(\mathrm{mg} \mathrm{kg}^{-1}\right)\end{array}$ & $\begin{array}{c}\mathrm{F} 2 \\
\left(\mathrm{mg} \mathrm{kg}^{-1}\right)\end{array}$ & $\begin{array}{c}\mathrm{F} 3 \\
\left(\mathrm{mg} \mathrm{kg}^{-1}\right)\end{array}$ & $\begin{array}{l}\text { Residual } \\
\left(\mathrm{mg} \mathrm{kg}^{-1}\right)\end{array}$ & & \\
\hline As & $0.05 \pm 0.01$ & $5.5 \pm 0.2$ & $9.2 \pm 0.3$ & $19.1 \pm 0.6$ & $33.9 \pm 1.3$ & $44 \pm 7$ \\
\hline $\mathrm{Cd}$ & $0.03 \pm 0.01$ & $0.03 \pm 0.02$ & $0.05 \pm 0.01$ & $0.10 \pm 0.03$ & $0.21 \pm 0.04$ & $53 \pm 10$ \\
\hline Co & $0.7 \pm 0.2$ & $5.2 \pm 0.9$ & $0.24 \pm 0.05$ & $1.8 \pm 0.1$ & $8.0 \pm 0.8$ & $77 \pm 10$ \\
\hline $\mathrm{Cr}$ & $1.2 \pm 0.2$ & $2.3 \pm 0.8$ & $3.4 \pm 0.1$ & $15.4 \pm 0.3$ & $22.3 \pm 1.3$ & $31 \pm 12$ \\
\hline $\mathrm{Cu}$ & $1.8 \pm 0.1$ & $1.4 \pm 0.2$ & $1.4 \pm 0.1$ & $3.3 \pm 0.2$ & $7.9 \pm 0.4$ & $58 \pm 6$ \\
\hline $\mathrm{Ni}$ & $0.46 \pm 0.08$ & $0.30 \pm 0.03$ & $1.1 \pm 0.3$ & $4.0 \pm 0.4$ & $5.9 \pm 0.8$ & $32 \pm 9$ \\
\hline $\mathrm{Pb}$ & $2.0 \pm 0.4$ & $1.5 \pm 0.1$ & $2.2 \pm 0.4$ & $8.3 \pm 0.3$ & $14.1 \pm 0.9$ & $41 \pm 7$ \\
\hline $\mathrm{Zn}$ & $4.0 \pm 0.7$ & $1.4 \pm 0.2$ & $4.5 \pm 0.7$ & $30.2 \pm 0.1$ & $40.1 \pm 1.3$ & $25 \pm 8$ \\
\hline
\end{tabular}

fractionation of trace elements (Figure 3), their quantities increased in the fractions available after deposition of the mud layer on the sediment samples. Thus, the trace elements present in the available fractions are more sensitive to variations in environmental conditions, and can be more easily remobilized into the aquatic environment. Moreover, the increase in acidity of the water causes dissolution of carbonaceous structures present in the river beds, making the trace elements available to the water. ${ }^{10}$ The trace elements $\mathrm{Cd}, \mathrm{Co}$, $\mathrm{Cr}, \mathrm{Cu}, \mathrm{Ni}, \mathrm{Pb}$ and $\mathrm{Zn}$ in some water samples (Table 6) collected after deposition of the mud layer also presented higher values than previously found (first collection), however they were lower than the limit established by Brazilian environmental legislation. ${ }^{48}$ 
Table 5. Total As level and physical-chemical parameters related to water quality

\begin{tabular}{|c|c|c|c|c|c|}
\hline & Total As $\left(\mu \mathrm{g} \mathrm{L}^{-1}\right)$ & $\mathrm{pH}$ & Redox Potential & Temperature $\left({ }^{\circ} \mathrm{C}\right)$ & $\begin{array}{c}\text { Dissolved Oxygen } \\
\quad\left(\mathrm{mg} \mathrm{L}^{-1}\right)\end{array}$ \\
\hline $\mathrm{BES}^{\mathrm{a}}$ & $<10$ & $6.0-9.0$ & & & $>5$ \\
\hline \multicolumn{6}{|c|}{ Sampling Sites } \\
\hline S1 & $10.9 \pm 0.4$ & 7.8 & 186 & 16.1 & 5.4 \\
\hline S2 & $34.3 \pm 0.5$ & 7.8 & 215 & 17.2 & 5.7 \\
\hline S3 & $42.6 \pm 0.2$ & 6.9 & 172 & 18.4 & 5.6 \\
\hline S4 & $37.5 \pm 0.2$ & 7.7 & 128 & 19.0 & 6.0 \\
\hline S5 & $35.5 \pm 0.8$ & 6.8 & 173 & 19.2 & 5.9 \\
\hline S6 & $50.4 \pm 0.8$ & 7.9 & 158 & 20.5 & 5.4 \\
\hline S7 & $44.1 \pm 0.4$ & 7.2 & 160 & 21.8 & 5.6 \\
\hline S8 & $39.6 \pm 0.8$ & 7.6 & 212 & 21.9 & 6.6 \\
\hline S9 & $32.5 \pm 0.5$ & 7.2 & 240 & 23.3 & 6.9 \\
\hline S10 & $29.2 \pm 0.2$ & 7.7 & 189 & 22.9 & 6.1 \\
\hline S11 & $12.2 \pm 0.2$ & 7.4 & 205 & 24.1 & 5.3 \\
\hline S12 & $15.2 \pm 0.3$ & 7.9 & 170 & 16.9 & 5.1 \\
\hline S13 & $10.4 \pm 0.5$ & 7.4 & 202 & 22.6 & 6.5 \\
\hline S11a & $25.0 \pm 1.0$ & 7.2 & 157 & 22.7 & 5.3 \\
\hline S12a & $23.0 \pm 1.5$ & 6.9 & 178 & 21.5 & 5.6 \\
\hline S13a & $14.5 \pm 2.5$ & 6.9 & 199 & 17.8 & 5.8 \\
\hline
\end{tabular}

${ }^{a}$ Values established by Brazilian environmental standards (BES) for water destined for human consumption (CONAMA 2005).

Table 6. Total metals level in samples of water

\begin{tabular}{|c|c|c|c|c|c|c|c|}
\hline & \multicolumn{7}{|c|}{ Concentration in $\mu \mathrm{g} \mathrm{L} \mathrm{L}^{-1}$} \\
\hline & $\mathrm{Cd}$ & Co & $\mathrm{Cr}$ & $\mathrm{Cu}^{\mathrm{b}}$ & $\mathrm{Ni}$ & $\mathrm{Pb}$ & $\mathrm{Zn}$ \\
\hline $\mathrm{BES}^{\mathrm{a}}$ & 1 & --- & 50 & 9 & 25 & 30 & 180 \\
\hline \multicolumn{8}{|c|}{ Sampling sites } \\
\hline S1 & $0.18 \pm 0.05$ & $0.82 \pm 0.05$ & $1.4 \pm 0.1$ & $0.70 \pm 0.19$ & $9.3 \pm 0.2$ & $5.1 \pm 0.1$ & $52.7 \pm 1.5$ \\
\hline S2 & $0.42 \pm 0.01$ & $0.75 \pm 0.01$ & $5.7 \pm 0.2$ & $0.75 \pm 0.20$ & $22.6 \pm 0.8$ & $8.1 \pm 0.5$ & $19.4 \pm 0.8$ \\
\hline S3 & $0.24 \pm 0.01$ & $0.17 \pm 0.05$ & $5.6 \pm 0.2$ & $0.41 \pm 0.03$ & $11.8 \pm 0.5$ & $4.1 \pm 0.5$ & $18.8 \pm 0.2$ \\
\hline S4 & $0.12 \pm 0.01$ & $2.4 \pm 0.1$ & $2.7 \pm 0.1$ & $0.93 \pm 0.13$ & $4.1 \pm 0.3$ & $4.0 \pm 0.5$ & $12.5 \pm 0.8$ \\
\hline S5 & $0.32 \pm 0.05$ & $0.79 \pm 0.05$ & $4.6 \pm 0.2$ & $0.26 \pm 0.03$ & $4.0 \pm 0.3$ & $5.0 \pm 0.7$ & $22.0 \pm 0.8$ \\
\hline S6 & $0.54 \pm 0.05$ & $0.35 \pm 0.06$ & $4.9 \pm 0.2$ & $0.63 \pm 0.06$ & $4.7 \pm 0.3$ & $1.2 \pm 0.1$ & $10.8 \pm 0.6$ \\
\hline S7 & $0.53 \pm 0.02$ & $0.17 \pm 0.02$ & $1.6 \pm 0.5$ & $0.39 \pm 0.05$ & $2.4 \pm 0.2$ & $0.20 \pm 0.3$ & $30.4 \pm 0.9$ \\
\hline S8 & $0.75 \pm 0.02$ & $1.6 \pm 0.2$ & $1.2 \pm 0.4$ & $0.46 \pm 0.06$ & $9.3 \pm 0.2$ & $5.3 \pm 0.5$ & $12.2 \pm 1.0$ \\
\hline S9 & $0.54 \pm 0.01$ & $0.55 \pm 0.02$ & $1.9 \pm 0.2$ & $0.43 \pm 0.05$ & $2.1 \pm 0.1$ & $0.67 \pm 0.06$ & $46.7 \pm 0.4$ \\
\hline S10 & $0.47 \pm 0.05$ & $0.50 \pm 0.05$ & $1.7 \pm 0.2$ & $0.20 \pm 0.03$ & $2.1 \pm 0.5$ & $1.4 \pm 0.1$ & $17.7 \pm 0.1$ \\
\hline S11 & $0.65 \pm 0.02$ & $0.70 \pm 0.05$ & $5.0 \pm 0.4$ & $0.67 \pm 0.13$ & $3.9 \pm 0.1$ & $2.3 \pm 0.5$ & $2.6 \pm 0.4$ \\
\hline S12 & $0.24 \pm 0.01$ & $0.30 \pm 0.05$ & $4.2 \pm 0.4$ & $0.53 \pm 0.15$ & $0.39 \pm 0.06$ & $0.41 \pm 0.08$ & $5.9 \pm 0.1$ \\
\hline S13 & $0.16 \pm 0.05$ & $1.1 \pm 0.2$ & $3.6 \pm 0.7$ & $0.91 \pm 0.05$ & $0.55 \pm 0.06$ & $0.57 \pm 0.1$ & $5.7 \pm 0.5$ \\
\hline S11a & $0.50 \pm 0.05$ & $2.0 \pm 0.5$ & $7.7 \pm 0.6$ & $0.44 \pm 0.02$ & $4.6 \pm 0.4$ & $2.6 \pm 0.6$ & $54.6 \pm 1$ \\
\hline S12a & $0.35 \pm 0.01$ & $2.5 \pm 0.5$ & $5.3 \pm 0.5$ & $0.42 \pm 0.06$ & $1.2 \pm 0.3$ & $3.8 \pm 0.2$ & $74.0 \pm 0.1$ \\
\hline S13a & $0.30 \pm 0.02$ & $1.8 \pm 0.3$ & $6.5 \pm 0.4$ & $0.46 \pm 0.08$ & $1.4 \pm 0.6$ & $2.9 \pm 0.5$ & $76.9 \pm 0.4$ \\
\hline
\end{tabular}

${ }^{\mathrm{a}}$ Values established by Brazilian environmental standards (BES) to human supply-destined waters (CONAMA 2005), ${ }^{\mathrm{b}} \mathrm{Cu}$ dissolved.

Although the quantity of As in the water samples from the first collection was already above the maximum limit recommended by the local regulatory agency, after deposition of the mud layer there was an increase in its concentration, increasing the risk to the local population. Among the possible water contaminants, arsenic is one of the most problematic, being considered by the World Health Organization (WHO) as one of the most important with regards to global public health. ${ }^{51}$ Consumption of water containing arsenic can 
cause dermatitis, skin cancer, neurological disorders, hepatomegaly, cardiac problems, internal cancers and poisoning..$^{52,53}$

\section{CONCLUSIONS}

The present study evaluated the total contents of trace elements in the water and their partitions in the sediment of samples collected in the Tripuí Creek and the Carmo River, in the Iron Quadrangle of southeast Brazil. The $\sim 22 \mathrm{~km}$ stretch of the Carmo River was contaminated with tailings mud from the rupture of the Fundão dam. In the present study we collected samples in this stretch of the Carmo River six months before the environmental accident. Thus, for the purpose of comparison a new collection was performed six months after the mud deposition, which allowed for verifying changes in the total amount of trace elements in the water and their partitions in the sediment.

The results showed that the total As concentration in the water ranged from 10.4 to $50.4 \mu \mathrm{g} \mathrm{L}^{-1}$ for the Carmo River, exceeding the maximum limit (>10 $\mathrm{g} \mathrm{L} \mathrm{L}^{-1}$ ) defined by Brazilian environmental regulations. Based on the water analysis, the $\mathrm{Cd}, \mathrm{Cr}, \mathrm{Ni}, \mathrm{Pb}$ and $\mathrm{Zn}$ concentrations studied were below the maximum limits defined by Brazilian standards.

The $\sim 2 \mathrm{~km}$ stretch of the Carmo River which received the tailings mud corresponded to the last three sampling points, where the total As concentrations in the water were $12.2,15.2$ and $10.4 \mu \mathrm{g} \mathrm{L}^{-1}$ and 25.0, 23.0 and $14.5 \mu \mathrm{g} \mathrm{L}^{-1}$ in the absence and presence of the tailings mud, respectively. Thus it was verified that the mud can potentiate the mobilization of trace elements from the sediment to the water.

Sediment analyses showed that the highest portion of trace elements extracted was associated with the residual fraction. However, considerable quantities were extracted as easily remobilized fractions, indicating potential for remobilization of these elements from the sediment to the aquatic environment. The mobility was in the order $\mathrm{Cd}>\mathrm{Cu}>\mathrm{Ni}>\mathrm{Co}>\mathrm{Cr}>\mathrm{Pb}>\mathrm{Zn}>\mathrm{As}$, with the elements $\mathrm{Cd}, \mathrm{Cu}$ and $\mathrm{Ni}$ being preferentially associated with the most labile fractions. After deposition of the tailing mud layer on the sediments, the average percentage of extracted metals in the available fractions followed the same decreasing order of availability, but there was an increase in the amount of As (20\%), Cd (13\%), Co (5\%), Cr (9\%), Cu (11\%), $\mathrm{Ni}(4 \%), \mathrm{Pb}(7 \%)$ and $\mathrm{Zn}(19 \%)$ in the easily remobilized fractions. Therefore, the increase in the amount of trace elements in the easily remobilized fractions, which is a potential human health risk, should not be ignored because the waterways of this region are destined for human consumption.

\section{SUPPLEMENTARY INFORMATION}

Supplementary data (Table $1 \mathrm{~S}$, Table $2 \mathrm{~S}$ and Table $3 \mathrm{~S}$ ) are available free of charge at http://quimicanova.sbq.org.br as PDF file.

\section{ACKNOWLEDGEMENT}

The authors acknowledge the financial support of the Fundação de Amparo à Pesquisa do Estado de Minas Gerais (FAPEMIG, Universal Demand, process No. APQ-00445-14) and the Conselho Nacional de Desenvolvimento Científico e Tecnológico (CNPq) and CAPES.

\section{REFERENCES}

1. Marta-Almeida, M.; Mendes, R.; Amorim, F. N.; Cirano, M.; Dias, J. M.; Mar. Pollut. Bull. 2016, 112, 359.

2. Segura, F. R.; Nunes, E. A.; Paniz, F. P.; Paulelli, A. C. C.; Rodrigues, G. B.; Braga, G. Ú. L.; dos Reis Pedreira Filho, W.; Barbosa, F.; Cerchiaro, G.; Silva, F. F.; Batista, B. L.; Environ. Pollut. 2016, $218,813$.
3. Carmo, F. F. do; Kamino, L. H. Y.; Junior, R. T.; Campos, I. C. de; Carmo, F. F. do; Silvino, G.; Castro, K. J. da S. X. de; Mauro, M. L.; Rodrigues, N. U. A.; Miranda, M. P. de S.; Pinto, C. E. F.; Perspect. Ecol. Conserv. 2017.

4. IBAMA - Instituto Brasileiro do Meio Ambiente e dos Recursos Naturais Renovaveis, Ministerio do Meio Ambiente. Diretoria de Protecao Ambiental - DIPRO e Coordenacao Geral de Emergencias Ambientais - CGEMA. Laudo Técnico Preliminar: Impactos ambientais decorrentes do desastre envolvendo o rompimento da barragem de Fundão, em Mariana, Minas Gerais, Novembro de 2015, p. 38. Available in http://www.ibama.gov.br/phocadownload/noticias_ ambientais/laudo_tecnico_preliminar.pdf., 2015.

5. Garcia, L. C.; Ribeiro, D. B.; De Oliveira Roque, F.; Ochoa-Quintero, J. M.; Laurance, W. F.; Ecol. Appl. 2017, 27, 5.

6. Borba, R. P.; Figueiredo, B. R.; Rawlins, B.; Matschullat, J.; Rev. Bras. Geociências 2000, 30, 558.

7. Mello, J. W. V; Roy, W. R. *.; Talbott, J. L.; Stucki, J. W.; J. Soils Sediments 2006, 6, 9 .

8. Borba, R. P.; Figueiredo, B. R.; Rev. Bras. Geocienc. 2004, 34, 489.

9. Matschullat, J.; Perobelli Borba, R.; Deschamps, E.; Figueiredo, B. R.; Gabrio, T.; Schwenk, M.; Appl. Geochem. 2000, 15, 181.

10. Borba, R. P.; Figueiredo, B. R.; Matschullat, J.; Environ. Geol. 2003, 44, 39.

11. Varejão, E. V. V; Bellato, C. R.; Fontes, M. P. F.; Mello, J. W. V.; Environ. Monit. Assess. 2011, 172, 631.

12. Devesa-rey, R.; Díaz-fierros, F.; Barral, M. T.; J. Environ. Manage. 2010, 91, 2471.

13. Alonso Castillo, M. L.; Vereda Alonso, E.; Siles Cordero, M. T.; Cano Pavón, J. M.; García de Torres, A.; Microchem. J. 2011, 98, 234.

14. Ianni, C.; Magi, E.; Soggia, F.; Rivaro, P.; Frache, R.; Microchem. J. 2010, 96, 203

15. Sundaray, S. K.; Nayak, B. B.; Lin, S.; Bhatta, D.; J. Hazard. Mater. 2011, 186, 1837.

16. Mihajlovic, J.; Stärk, H.-J.; Rinklebe, J.; Geoderma 2014, 228-229, 160.

17. Nemati, K.; Bakar, N. K. A.; Abas, M. R.; Sobhanzadeh, E.; J. Hazard. Mater. 2011, 192, 402.

18. Yıldırım, G.; Tokalığlu, S.; Ecotoxicol. Environ. Saf. 2016, 124, 369.

19. Passos, E. de A.; Alves, J. C.; dos Santos, I. S.; Alves, J. do P. H.; Garcia, C. A. B.; Spinola Costa, A. C.; Microchem. J. 2010, 96, 50.

20. Sungur, A.; Soylak, M.; Ozcan, H.; Chem. Speciation Bioavailability 2014, 26, 219.

21. Ahumada, I.; Marican, A.; Retamal, M.; Pedraza, C.; Ascar, L.; Carrasco, A.; Richter, P.; J. Braz. Chem. Soc. 2010, 21, 721.

22. Nemati, K.; Kartini, N.; Bakar, A.; Sobhanzadeh, E.; Abas, M. R.; Microchem. J. 2009, 92, 165.

23. Abollino, O.; Malandrino, M.; Giacomino, A.; Mentasti, E.; Anal. Chim. Acta 2011, 688, 104.

24. Sungur, A.; Soylak, M.; Yilmaz, S.; Özcan, H.; Environ. Earth Sci. 2014, $72,3293$.

25. Tessier, A.; Campbell, P. G. C.; Bisson, M.; Anal. Chem. 1979, 51, 844.

26. Rauret, G.; López-Sánchez, J. F.; Sahuquillo, A.; Rubio, R.; Davidson, C.; Ure, A.; Quevauviller, P.; J. Environ. Monit. 1999, 1, 57.

27. Ure, A. M.; Quevauviller, P.; Muntau, H.; Griepink, B.; Int. J. Environ. Anal. Chem. 1993, 51, 135.

28. Ma, X.; Zuo, H.; Tian, M.; Zhang, L.; Meng, J.; Zhou, X.; Chemosphere 2016, 144, 264.

29. Prohic, E.; Kniewald, G.; Mar. Chem. 1987, 22, 279.

30. Zemberyová, M.; Barteková, J.; Hagarová, I.; Talanta 2006, 70, 973.

31. Donagema, G. K.; Campos, D. V. B. de; Calderano, S. B.; Teixeira, W. G.; Viana, J. H. M.; Manual de Métodos de Análise de Solo, $2^{\text {nd }}$ ed., Embrapa Solos: Rio de Janeiro, 2011.

32. Mebius, L. J.; Anal. Chim. Acta 1960, 22, 120. 
33. Yeomans, J. C.; Bremner, J. M.; Commun. Soil Sci. Plant Anal. 1988, 19, 1467.

34. Ruiz, H. A.; Rev. Bras. Cienc. Solo 2005, 29, 297.

35. Junior, R. a M.; Mimura, A. M. S.; Divino, A. C.; Silva, R. F.; Silva, J. C. J.; Ciminelli, V. S. T.; Soil Sediment Contam. 2014, 23, 257.

36. Passos, E. D. A.; Alves, J. D. P. H.; Garcia, C. A. B.; Costa, A. C. S.; J. Braz. Chem. Soc. 2011, 22, 828.

37. Rieuwerts, J. S.; Ashmore, M. R.; Farago, M. E.; Thornton, I.; Sci. Total Environ. 2006, 366, 864.

38. Fernandez, R. O.; Giraldez Cervera, J. V.; Vanderlinden, K.; Carbonell Bojollo, R.; Gonzalez Fernandez, P.; Water. Air. Soil Pollut. 2007, 178, 229.

39. CONAMA - Conselho Nacional do Meio Ambiente. Resolução No. 454. Brasil: Ministerio do Desenvolvimento Urbano e Meio Ambiente, Brasilia, 2012.

40. Guillén, M. T.; Delgado, J.; Albanese, S.; Nieto, J. M.; Lima, A.; De Vivo, B.; J. Geochem. Explor. 2012, 119-120, 32.

41. Yang, Y.; Chen, F.; Zhang, L.; Liu, J.; Wu, S.; Kang, M.; Mar. Pollut. Bull. 2012, 64, 1947.

42. Kartal, Ş.; Aydin, Z.; Tokalioğlu, Ş.; J. Hazard. Mater. 2006, 132, 80.

43. Zhuang, W.; Liu, Y.; Chen, Q.; Wang, Q.; Zhou, F.; Ecol. Indic. 2016, $69,252$.

44. Wali, A.; Colinet, G.; Ksibi, M.; Environ. Res. Eng. Manag. 2015, 70, 14.

45. Botsou, F.; Sungur, A.; Kelepertzis, E.; Soylak, M.; Ecotoxicol. Environ. Saf. 2016, 132, 101.
46. Li, Y.; Cai, X.; Guo, J.; Zhou, S.; Na, P.; Appl. Surf. Sci. 2015, 324, 179. 47. Liu, H.; Li, L.; Yin, C.; Shan, B.; J. Environ. Sci. (China) 2008, 20, 390.

48. CONAMA - Conselho Nacional do Meio Ambiente. Resolução No. 357. Brasil: Ministério do Desenvolvimento Urbano e Meio Ambiente, Brasília., 2005.

49. SEMAD-IGAM - Sistema Estadual de Meio Ambiente - Instituto Mineiro de Gestão das Águas Governo do Estado de Minas Gerais. MONITORAMENTO DA QUALIDADE DAS AGUAS SUPERFICIAIS DO RIO DOCE NO ESTADO DE MINAS GERAIS, RELATORIO TECNICO Acompanhamento da Qualidade das Aguas do Rio Doce Apos o Rompimento da Barragem da Samarco no distrito de Bento Rodrigues - Mariana/MG. 01 DE FEVEREIRO DE 2016, p. 75. Available in http://www.igam.mg.gov.br/component/content/ article/16/1632-monitoramento-da-qualidade-das-aguas-superficiaisdo-rio-doce-no-estadode minas-gerais, 2015.

50. CPRM. Servico Geologico do Brasil, 2015. MONITORAMENTO ESPECIAL DO RIO DOCE: RELATORIO 02 Geoquimica. Segunda Campanha de Campo 12 a 23 de novembro de 2015. Belo Horizonte - MG, Brasil. http://www.cprm.gov.br/ publique/media/RT_02_2015_ MONIT_ESP_BACIA_RIO_DOCE_v4_5.pdf, 2015.

51. Guidelines for drinking-water quality, $3^{\text {rd }}$ ed., World Health Organization: Geneva, 2004.

52. Marques Neto, J. O.; Bellato, C. R.; Milagres, J. L.; Pessoa, K. D.; De Alvarenga, E. S.; J. Braz. Chem. Soc. 2013, 24, 121.

53. Shevade, S.; Ford, R. G.; Water Res. 2004, 38, 3197 